Review

\title{
Recent Advances in the Substitution Reactions of Triorganylstannyl Ions with Aromatic Compounds by the $S_{R N} 1$ Mechanism. Synthetic Applications
}

\author{
Eduardo F. Córsico, Al Postigo and Roberto A. Rossi*
}

INFIQC, Departamento de Química Orgánica, Facultad de Ciencias Químicas, Universidad Nacional de Córdoba. Ciudad Universitaria, 5000 Córdoba, Argentina

Tel.: (54) (351) 433-4170, Fax: (54) (351) 433-3030, E-mail: rossi@ dqo.fcq.unc.edu.ar

Received: 30 May 2000; revised form 18August 2000/Accepted: 5 September 2000/Published: 11 September 2000

\begin{abstract}
A review on the reactions of triorganyl stannyl ions with haloarenes is presented. Emphasis on the synthetic applications of the resulting triorganyl stannyl aryl compounds is made, with their inherent potential to build large molecules through the $S_{\mathrm{RN}} 1$ sequence, i.e. $\mathrm{ArX} \rightarrow \mathrm{ArSnR}_{3} \rightarrow \mathrm{ArAr}$, which can be iteratively repeated when appropriately substituted substrates are chosen.
\end{abstract}

Keywords: stannyl anions, $\mathrm{S}_{\mathrm{RN}} 1$, Stille reactions.

\section{Introduction}

The reaction of triorganostannyl ions as nucleophiles with haloarenes has long been known, and the products obtained depend on the nucleophile, solvent, and on the reaction conditions. Thus, the reactions of sodium trimethyltin $\left(\mathrm{NaSnMe}_{3}\right)$ with halobenzenes (chloro-, bromo- and iodo-) in tetraglyme as solvent afford phenyltrimethyltin $\left(\mathrm{Me}_{3} \mathrm{SnPh}\right)$ and variable amounts of reduction product benzene along with diphenyldimethyltin $\left(\mathrm{Ph}_{2} \mathrm{SnMe}_{2}\right)$ and tetramethyltin $\left(\mathrm{SnMe}_{4}\right)$. From trapping experiments and solvent effects it has been proposed that the reaction occurs by a halogen metal exchange (HME) mechanism in a solvent cage. The formation of secondary products, $\mathrm{Ph}_{2} \mathrm{SnMe}_{2}$ and $\mathrm{SnMe}_{4}$, has been ascribed to the decomposition of $\mathrm{NaSnMe}_{3}$ into $\mathrm{NaMe}$ and dimethylstannylene [1]. The reaction of $o$-dibromobenzene with $\mathrm{NaSnMe}_{3}$ affords the disubstitution product $o$-bis(trimethylstannyl) benzene in $42 \%$ yield. In this reaction, the intermediate $o$-bromophenyl anion, can decompose into benzyne, which can then be trapped with furan to render the corresponding Diels- 
Alder adduct [2].

The reaction of $o-, m$ - and $p$-bromotoluenes with $\mathrm{LiSnBu}_{3}$ in THF as solvent affords the expected substitution product, but when $p$-chloro and $p$-fluorotoluenes are used as substrates, cine substitution products are obtained, indicating that a benzyne mechanism operates. When radical traps are added, cine substitution products increase in yields, and in the presence of Li metal, the yields of ipso products are enhanced. According to these results, the reaction should proceed, at least in part, by a radical mechanism [3]. No light stimulation was employed in these reactions.

There are several methods of synthesis for trialkylarylstannanes, typically by the reaction of aryl lithium or organomagnesium derivatives with trialkyltin halides. These reactions have the drawback that many substituents on the aromatic ring are incompatible with the formation of aryl lithium or organo-magnesium derivatives [4]. We have described the photostimulated reactions of haloarenes with triorganylstannyl ions by the $\mathrm{S}_{\mathrm{RN}} 1$ mechanism. These reactions afford good to excellent yields of the nucleophilic substitution products. Many substituents are compatible with the $\mathrm{S}_{\mathrm{RN}} 1$ mechanism, such as $\mathrm{CO}_{2}^{-}, \mathrm{CO}_{2} \mathrm{R}, \mathrm{CONR}_{2}, \mathrm{RO}-,-\mathrm{CN}, \mathrm{R}$, aryl, $\mathrm{NH}_{2}, \mathrm{NR}_{2}$ and $\mathrm{SO}_{2} \mathrm{R}$. [5] Another approach is the palladium catalysis (Stille reaction) of aryl halides [6] or aryl triflates [7] with hexamethyl- and hexabutyl-distannanes. Bis(trimethylstannyl) arenes can also be synthesized by palladium catalysis; the yields of disubstitution products range from 40 to $60 \%$ [8]. There are few examples involving reactions of bis(trimethylstannyl) arenes and heteroarenes with aryl halides, which afford a double arylation by the palladium cross-coupling reaction. The examples known afford modest to good yields (6-85\% yield) of double arylation $[9,10,11]$.

The $\mathrm{S}_{\mathrm{RN}} 1$ mechanism is a chain process, whose main steps are presented in Scheme 1.

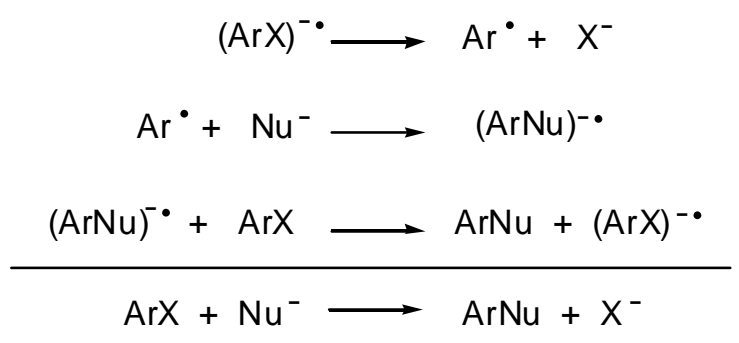

\section{Scheme 1.}

Overall, eqs. 1-3 depict a nucleophilic substitution (eq. 1,3) in which radicals and radical anions are intermediates. This chain process requires an initiation step. In a few systems, spontaneous electron transfer (ET) from the nucleophile to the substrate has been observed. When the ET does not occur spontaneously, it can often be induced by light stimulation.

In this review we present the results of the reactions of organotin nucleophiles with aryl halides by the $\mathrm{S}_{\mathrm{RN}} 1$ mechanism and their synthetic applications. Reactions are compiled in Tables 1 and 2.

\section{2. $\mathrm{Me}_{3} \mathrm{Sn}^{-}$Ions as Nucleophile}

Trimethylstannyl anion $\left(\mathrm{Me}_{3} \mathrm{Sn}^{-}\right)$is prepared in liquid ammonia through the reaction of $\mathrm{Me}_{3} \mathrm{SnCl}$ with $\mathrm{Na}$ metal. $p$-Chloroanisole (1) does not react with $\mathrm{Me}_{3} \mathrm{Sn}^{-}$ions in the dark after $1 \mathrm{~h}$, but upon irradiation $(\mathrm{Hg}$ lamp, $366 \mathrm{~nm}, 1 \mathrm{~h}$ ), substitution product 2 was obtained in ca. 100\% yield (Table I) (eq. 4). The photostimulated reaction is inhibited by $p$-dinitrobenzene, a well-known inhibitor of $\mathrm{S}_{\mathrm{RN}} 1$ processes [12]. 
$\underbrace{}_{\text {OMe }}+\mathrm{Me}_{3} \mathrm{Sn}^{-} \frac{\mathrm{h}}{\mathrm{NH}_{3}}+\mathrm{Cl}_{\text {OMe }}^{\mathrm{SI}}$

1

Conversely, $p$-bromoanisole in the presence of $\mathrm{Me}_{3} \mathrm{Sn}^{-}$ions affords exclusively anisole in the dark. This reaction proceeds by a HME, with a very fast protonation of the $p$-anisyl anion by liquid ammonia, anisole being the only product obtained. Bromides and iodides will likely react by a HME reaction faster than by the $\mathrm{S}_{\mathrm{RN}} 1$ mechanism. When 2-chloroquinoline is allowed to react in the dark with $\mathrm{Me}_{3} \mathrm{Sn}^{-}$ions, low yields of the respectively-substituted product are obtained, a reaction which is inhibited by $p$-DNB and accelerated by light (96\%). Other examples are indicated in Table I.

Aryldiethylphosphates are as good leaving groups as chlorines, and they both react with amide ions, $\mathrm{NH}_{2}{ }^{-}$, to afford substitution products by the $\mathrm{S}_{\mathrm{RN}} 1$ mechanism [13]. The synthesis of aryl trimethylstannanes from phenols through aryldiethylphosphates has recently been reported to proceed in high yields in liquid ammonia. For instance, the photostimulated reaction of $\mathbf{3}$ with $\mathrm{Me}_{3} \mathrm{Sn}^{-}$ions affords the substitution product $\mathbf{4}$ in $93 \%$ yield (eq. 5) [14]. These reactions do not occur in the dark.<smiles>Oc1cccc2ccccc12</smiles>

3<smiles>CSc1cccc2ccccc12</smiles>

4

Phenyltrimethyl ammonium salts also react with $\mathrm{Me}_{3} \mathrm{Sn}^{-}$ions in liquid ammonia to give the substitution product in high yields (Table I) [15].

When the aromatic substrate bears two leaving groups, such as $p$-dichlorobenzene (5), disubstitution product 6 is isolated in $88 \%$ yield (eq. 6). The monosubstitution product is not an intermediate in these reactions.<smiles>CSc1ccc(SCC(C)C)cc1</smiles>

5
6
With two different leaving groups, such as in 7, compound $\mathbf{6}$ is obtained in excellent yields as well (eq. 7).<smiles>CCOc1ccc(Cl)cc1</smiles> 
Substrates such as 2,5-, 2,6- and 3,5- dichloropyridines afford the respective disubstitution products in $80-86 \%$ yields [16] (Table I). There is a report where several chloro, bromo, dichloro and dibromo pyridines and quinolines react with $\mathrm{Me}_{3} \mathrm{Sn}^{-}$ions in dimethoxyethane to render the mono and disubstitution products in $60-88 \%$ yields. There is no photostimulation in these reactions, and no information is provided about the mechanism [17].

We have found that the photostimulated reaction of 1,3,5-trichlorobenzene $\mathbf{8}$ in the presence of an excess of $\mathrm{Me}_{3} \mathrm{Sn}^{-}$ions affords $71 \%$ of the trisubstitution product 9 (eq. 8).

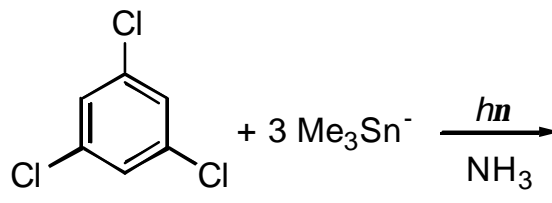

8<smiles>CSc1cc([AsH2]C)cc(S(C)(C)C)c1</smiles>

9

Table 1. Reactions of $\mathrm{Me}_{3} \mathrm{Sn}^{-}$ions with aromatic compounds in liquid ammonia by the $\mathrm{S}_{\mathrm{RN}} 1$ mechanism.

\begin{tabular}{|c|c|c|c|}
\hline$\underline{\text { Substrate }}$ & Conditions & Products (Yields \%) & Ref. \\
\hline$p-\mathrm{MeOC}_{6} \mathrm{H}_{4} \mathrm{Cl}$ & Dark, $1 \mathrm{~h}$ & $p-\mathrm{MeOC}_{6} \mathrm{H}_{4} \mathrm{SnMe}_{3}(0)$ & 12 \\
\hline$p-\mathrm{MeOC}_{6} \mathrm{H}_{4} \mathrm{Cl}$ & $h v, 1 \mathrm{~h}$ & $p-\mathrm{MeOC}_{6} \mathrm{H}_{4} \mathrm{SnMe}_{3}(100)$ & 12 \\
\hline$p-\mathrm{MeOC}_{6} \mathrm{H}_{4} \mathrm{Cl}$ & $h v, 1 \mathrm{~h}, p$-DNB & $p-\mathrm{MeOC}_{6} \mathrm{H}_{4} \mathrm{SnMe}_{3}(0)$ & 12 \\
\hline$p-\mathrm{MeOC}_{6} \mathrm{H}_{4} \mathrm{OP}(\mathrm{O})(\mathrm{OEt})_{2}$ & $h v, 1 \mathrm{~h}$ & $p-\mathrm{MeOC}_{6} \mathrm{H}_{4} \mathrm{SnMe}_{3}(81)$ & 14 \\
\hline $\mathrm{PhNMe}_{3} \mathrm{I}$ & $h v, 1 \mathrm{~h}$ & $\mathrm{PhSnMe}_{3}(98)$ & 15 \\
\hline$p-\mathrm{NCC}_{6} \mathrm{H}_{4} \mathrm{Cl}$ & $h v, 1 \mathrm{~h}$ & $p-\mathrm{NCC}_{6} \mathrm{H}_{4} \mathrm{SnMe}_{3}(85)$ & 16 \\
\hline $1-\mathrm{C}_{10} \mathrm{H}_{7} \mathrm{Cl}^{\mathrm{a}}$ & $h v, 1 \mathrm{~h}$ & $1-\mathrm{C}_{10} \mathrm{H}_{7} \mathrm{SnMe}_{3}(90)$ & 12 \\
\hline $1-\mathrm{C}_{10} \mathrm{H}_{7} \mathrm{OP}(\mathrm{O})(\mathrm{OEt})_{2}^{\mathrm{a}}$ & $h v, 1 \mathrm{~h}$ & $1-\mathrm{C}_{10} \mathrm{H}_{7} \mathrm{SnMe}_{3}(93)$ & 14 \\
\hline $2-\mathrm{C}_{5} \mathrm{H}_{4} \mathrm{NCl}^{\mathrm{b}}$ & $h v, 1.5 \mathrm{~h}$ & $2-\mathrm{C}_{5} \mathrm{H}_{4} \mathrm{NSnMe}_{3}(88)$ & 16 \\
\hline $2-\mathrm{C}_{9} \mathrm{H}_{6} \mathrm{NCl}^{\mathrm{c}}$ & Dark, $1 \mathrm{~h}$ & 2- $\mathrm{C}_{9} \mathrm{H}_{6} \mathrm{NSnMe}_{3}(65)$ & 12 \\
\hline $2-\mathrm{C}_{9} \mathrm{H}_{6} \mathrm{NCl}^{\mathrm{c}}$ & Dark, $1 \mathrm{~h}, p$-DNB & $2-\mathrm{C}_{9} \mathrm{H}_{6} \mathrm{NSnMe}_{3}(12)$ & 12 \\
\hline $2-\mathrm{C}_{9} \mathrm{H}_{6} \mathrm{NCl}^{\mathrm{c}}$ & $h v, 1 \mathrm{~h}$ & $2-\mathrm{C}_{9} \mathrm{H}_{6} \mathrm{NSnMe}_{3}(96)$ & 12 \\
\hline$o-\mathrm{Cl}_{2} \mathrm{C}_{6} \mathrm{H}_{4}$ & $h v, 1 \mathrm{~h}$ & $o-\left(\mathrm{Me}_{3} \mathrm{Sn}\right)_{2} \mathrm{C}_{6} \mathrm{H}_{4}(58)$ & 16 \\
\hline$m-\mathrm{Cl}_{2} \mathrm{C}_{6} \mathrm{H}_{4}$ & $h v, 1.5 \mathrm{~h}$ & $m-\left(\mathrm{Me}_{3} \mathrm{Sn}\right)_{2} \mathrm{C}_{6} \mathrm{H}_{4}(90)$ & 16 \\
\hline$p-\mathrm{Cl}_{2} \mathrm{C}_{6} \mathrm{H}_{4}$ & $h v, 1 \mathrm{~h}$ & $p-\left(\mathrm{Me}_{3} \mathrm{Sn}\right)_{2} \mathrm{C}_{6} \mathrm{H}_{4}(88)$ & 12 \\
\hline$p-\mathrm{ClC}_{6} \mathrm{H}_{4} \mathrm{OP}(\mathrm{O})(\mathrm{OEt})_{2}$ & $h v, 1 \mathrm{~h}$ & $p-\left(\mathrm{Me}_{3} \mathrm{Sn}\right)_{2} \mathrm{C}_{6} \mathrm{H}_{4}(97)$ & 14 \\
\hline$p-\mathrm{C}_{6} \mathrm{H}_{4}\left[\mathrm{OP}(\mathrm{O})(\mathrm{OEt})_{2}\right]_{2}$ & $h v, 1 \mathrm{~h}$ & $p-\left(\mathrm{Me}_{3} \mathrm{Sn}\right)_{2} \mathrm{C}_{6} \mathrm{H}_{4}(95)$ & 14 \\
\hline $2,5-\mathrm{C}_{5} \mathrm{H}_{3} \mathrm{NCl}_{2}^{\mathrm{b}}$ & $2 \mathrm{~h}$ & $2,5-\mathrm{C}_{5} \mathrm{H}_{3} \mathrm{~N}\left(\mathrm{Me}_{3} \mathrm{Sn}\right)_{2}(88)$ & 16 \\
\hline $3,5-\mathrm{C}_{5} \mathrm{H}_{3} \mathrm{NCl}_{2}^{\mathrm{b}}$ & $h v, 2 \mathrm{~h}$ & $3,5-\mathrm{C}_{5} \mathrm{H}_{3} \mathrm{~N}\left(\mathrm{Me}_{3} \mathrm{Sn}\right)_{2}(80)$ & 16 \\
\hline $2,6-\mathrm{C}_{5} \mathrm{H}_{3} \mathrm{NCl}_{2}^{\mathrm{b}}$ & $h v, 1.5 \mathrm{~h}$ & $2,6-\mathrm{C}_{5} \mathrm{H}_{3} \mathrm{~N}\left(\mathrm{Me}_{3} \mathrm{Sn}\right)_{2}(86)$ & 16 \\
\hline $1,3,5-\mathrm{Cl}_{3} \mathrm{C}_{6} \mathrm{H}_{3}$ & $h v, 1 \mathrm{~h}$ & $1,3,5-\left(\mathrm{Me}_{3} \mathrm{Sn}\right)_{3} \mathrm{C}_{6} \mathrm{H}_{3}(71)$ & 16 \\
\hline
\end{tabular}

${ }^{\mathrm{a}}$ Naphthyl. ${ }^{\mathrm{b}}$ Pyridyl. ${ }^{\mathrm{c}}$ Quinolyl. 


\section{3. $\mathrm{Ph}_{3} \mathrm{Sn}^{-}$Ions as Nucleophile}

Triphenylstannyl ion $\left(\mathrm{Ph}_{3} \mathrm{Sn}^{-}\right)$was prepared either from reaction of $\mathrm{Ph}_{3} \mathrm{SnCl}$ or $\mathrm{Ph}_{3} \mathrm{SnSnPh}_{3}$, with $\mathrm{Na}$ metal in liquid ammonia. $p$-Chloro or $p$-bromotoluenes 10 do not react with $\mathrm{Ph}_{3} \mathrm{Sn}^{-}$ions in the dark in liquid ammonia as solvent, but upon irradiation, substitution product 11 is obtained in good yields (eq. 9) (Table 2). $p$ Chloroanisole, under irradiation in DMSO, affords only $30 \%$ yield of the substitution product.

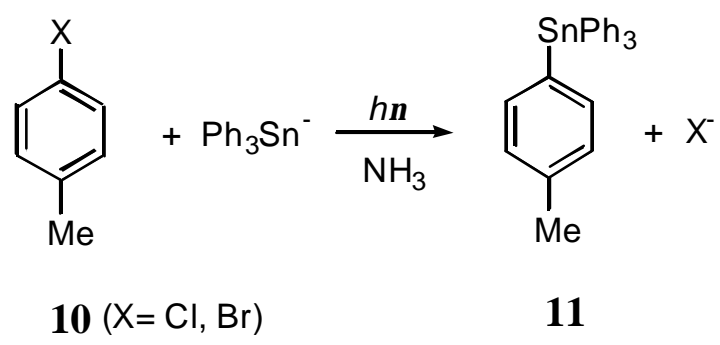

However, when $p$-iodotoluene and $p$-iodoanisole are utilized as substrates, a fast HME reaction takes place, affording the reduced product in the dark. Upon irradiation, low yields of substitution products are obtained by the $\mathrm{S}_{\mathrm{RN}} 1$ mechanism, which competes with the HME reaction (Table 2). In DMSO as solvent, only the HME reaction is observed.

1-Chloro and 1-bromo naphthalenes afford good yields of the substitution product when irradiated in liquid ammonia in the presence of $\mathrm{Ph}_{3} \mathrm{Sn}^{-}$ions. In DMSO as solvent, 1-chloronaphthalene affords good yields of substitution, i.e.: 1-(triphenylstannyl)naphthalene, however, the bromo derivative gives only the HME reaction. From these results it is concluded that the bromo derivatives react mainly by HME reaction in DMSO, but good yields of substitution products are obtained in liquid ammonia. 1- and 2- Naphthyldiethyl-phosphates 12 render excellent yields of substitution products 13 when irradiated in liquid ammonia in the presence of $\mathrm{Ph}_{3} \mathrm{Sn}^{-}$ ions (eq. 10).

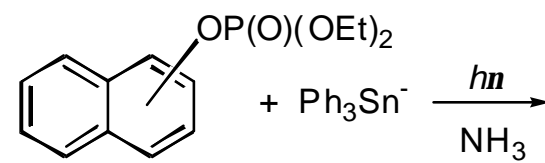

12<smiles>CCOc1cccc2cc([SbH])ccc12</smiles>

13

When $p$-dichlorobenzene is allowed to react with $\mathrm{Ph}_{3} \mathrm{Sn}^{-}$ions under photostimulation in liquid ammonia or DMSO, good yields of the disubstitution product are obtained (60\% or $90 \%$ respectively.) When $p$ dibromobenzene is utilized as substrate, there is a fast $\mathrm{HME}$ reaction to afford $\mathrm{PhBr}$. Upon irradiation, the disubstitution product, i.e.: $p$-bis(triphenyltin) benzene, is obtained in only $22 \%$ yield, along with tetraphenyltin, which arises from reaction of $\mathrm{PhBr}$ with $\mathrm{Ph}_{3} \mathrm{Sn}^{-}$ion.

$p$-Dibromobenzene reacts with $\mathrm{Ph}_{3} \mathrm{Sn}^{-}$ions in the absence of photostimulation to afford $96 \%$ yield of $\mathrm{PhBr}$. In the case of $\mathrm{ArI}$ as substrates and $\mathrm{Ph}_{3} \mathrm{Sn}^{-}$ions as nucleophile, the predominant reaction is the $\mathrm{HME}$ in liquid ammonia (Table 2). However, substrate 14, affords excellent yields of the disubstitution product 15 (eq. 11). 


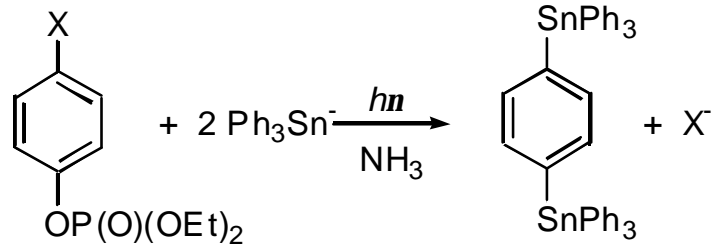

$14 \mathrm{X}=\mathrm{Br}, \mathrm{OP}(\mathrm{O})(\mathrm{OEt})_{2}$
15

of $\mathrm{Ph}_{3} \mathrm{Sn}^{-}$ions in liquid ammonia or DMSO. Thus, in DMSO, 2- and 3-chloropyridines afford, the substitution products in $82 \%$ and $93 \%$ yields respectively; and in liquid ammonia, 2-chloroquinoline furnishes 2(triphenyltin)quinoline in $80 \%$ yield (Table 2).

Table 2. Reactions of $\mathrm{Ph}_{3} \mathrm{Sn}^{-}$ions with aromatic compounds by the $\mathrm{S}_{\mathrm{RN}} 1$ mechanism.

\begin{tabular}{|c|c|c|c|}
\hline Substrate & Conditions & Products (Yield \%) & Ref. \\
\hline$p-\mathrm{MeC}_{6} \mathrm{H}_{4} \mathrm{Cl}$ & Dark, $\mathrm{NH}_{3}, 1 \mathrm{~h}$ & $p-\mathrm{MeC}_{6} \mathrm{H}_{4} \mathrm{SnPh}_{3}(0)$ & 12 \\
\hline$p-\mathrm{MeC}_{6} \mathrm{H}_{4} \mathrm{Cl}$ & $h v, \mathrm{NH}_{3}, 2 \mathrm{~h}$ & $p-\mathrm{MeC}_{6} \mathrm{H}_{4} \mathrm{SnPh}_{3}(75)$ & 12 \\
\hline$p-\mathrm{MeOC}_{6} \mathrm{H}_{4} \mathrm{Cl}$ & $h v, \mathrm{DMSO}, 24 \mathrm{~h}$ & $p-\mathrm{MeOC}_{6} \mathrm{H}_{4} \mathrm{SnPh}_{3}(30)$ & [18] \\
\hline$p-\mathrm{MeC}_{6} \mathrm{H}_{4} \mathrm{Br}$ & $h \mathrm{v}, \mathrm{NH}_{3}, 1 \mathrm{~h}$ & $p-\mathrm{MeC}_{6} \mathrm{H}_{4} \mathrm{SnPh}_{3}(62)$ & 12 \\
\hline$p-\mathrm{MeC}_{6} \mathrm{H}_{4} \mathrm{I}$ & $h v, \mathrm{NH}_{3}, 1 \mathrm{~h}$ & $p-\mathrm{MeC}_{6} \mathrm{H}_{4} \mathrm{SnPh}_{3}(38)$ & 12 \\
\hline$p-\mathrm{MeOC}_{6} \mathrm{H}_{4} \mathrm{I}$ & $h \mathrm{v}, \mathrm{NH}_{3}, 1 \mathrm{~h}$ & $p-\mathrm{MeOC}_{6} \mathrm{H}_{4} \mathrm{SnPh}_{3}(20)^{\mathrm{a}}$ & 12 \\
\hline $1-\mathrm{C}_{10} \mathrm{H}_{7} \mathrm{Cl}^{\mathrm{b}}$ & $h v, \mathrm{NH}_{3}, 3 \mathrm{~h}$ & $1-\mathrm{C}_{10} \mathrm{H}_{7} \mathrm{SnPh}_{3}(80)$ & 12 \\
\hline $1-\mathrm{C}_{10} \mathrm{H}_{7} \mathrm{Cl}^{\mathrm{b}}$ & $h \mathrm{v}, \mathrm{DMSO}, 4 \mathrm{~h}$ & $1-\mathrm{C}_{10} \mathrm{H}_{7} \mathrm{SnPh}_{3}(72)$ & 18 \\
\hline $1-\mathrm{C}_{10} \mathrm{H}_{7} \mathrm{Br}^{\mathrm{b}}$ & $h v, \mathrm{NH}_{3}, 1 \mathrm{~h}$ & $1-\mathrm{C}_{10} \mathrm{H}_{7} \mathrm{SnPh}_{3}(75)^{\mathrm{a}}$ & 12 \\
\hline $1-\mathrm{C}_{10} \mathrm{H}_{7} \mathrm{OP}(\mathrm{O})(\mathrm{OEt})_{2}{ }^{\mathrm{b}}$ & $h v, \mathrm{NH}_{3}, 4 \mathrm{~h}$ & $1-\mathrm{C}_{10} \mathrm{H}_{7} \mathrm{SnPh}_{3}(100)^{\mathrm{c}}$ & 14 \\
\hline $2-\mathrm{C}_{10} \mathrm{H}_{7} \mathrm{OP}(\mathrm{O})(\mathrm{OEt})_{2}^{\mathrm{b}}$ & $h v, \mathrm{NH}_{3}, 6 \mathrm{~h}$ & $2-\mathrm{C}_{10} \mathrm{H}_{7} \mathrm{SnPh}_{3}(100)^{\mathrm{c}}$ & 14 \\
\hline $2-\mathrm{C}_{5} \mathrm{H}_{4} \mathrm{NCl}^{\mathrm{d}}$ & $h v$, DMSO, $6 \mathrm{~h}$ & $2-\mathrm{C}_{5} \mathrm{H}_{4} \mathrm{NSnPh}_{3}(82)$ & 18 \\
\hline $3-\mathrm{C}_{5} \mathrm{H}_{4} \mathrm{NCl}^{\mathrm{d}}$ & $h v, \mathrm{DMSO}, 6 \mathrm{~h}$ & $3-\mathrm{C}_{5} \mathrm{H}_{4} \mathrm{NSnPh}_{3}(93)$ & 18 \\
\hline 2- $\mathrm{C}_{9} \mathrm{H}_{6} \mathrm{NCl}^{\mathrm{e}}$. & $h v, \mathrm{NH}_{3}, 1 \mathrm{~h}$ & $2-\mathrm{C}_{9} \mathrm{H}_{6} \mathrm{NSnPh}_{3}(80)$ & 12 \\
\hline$p-\mathrm{C}_{6} \mathrm{H}_{4} \mathrm{Cl}_{2}$ & $h v, \mathrm{NH}_{3}, 3 \mathrm{~h}$ & $p-\mathrm{C}_{6} \mathrm{H}_{4}\left[\mathrm{SnPh}_{3}\right]_{2}(69)$ & 12 \\
\hline$p-\mathrm{C}_{6} \mathrm{H}_{4} \mathrm{Cl}_{2}$ & $h v$, DMSO, $6 \mathrm{~h}$ & $p-\mathrm{C}_{6} \mathrm{H}_{4}\left[\mathrm{SnPh}_{3}\right]_{2}(90)$ & 18 \\
\hline$p-\mathrm{C}_{6} \mathrm{H}_{4} \mathrm{Br}_{2}$ & $h v, \mathrm{NH}_{3}, 1 \mathrm{~h}$ & $p-\mathrm{C}_{6} \mathrm{H}_{4}\left[\mathrm{SnPh}_{3}\right]_{2}(22)^{\mathrm{a}}$ & 12 \\
\hline$p-\mathrm{BrC}_{6} \mathrm{H}_{4} \mathrm{OP}(\mathrm{O})(\mathrm{OEt})_{2}$ & $h v, \mathrm{NH}_{3}, 2 \mathrm{~h}$ & $p-\mathrm{C}_{6} \mathrm{H}_{4}\left[\mathrm{SnPh}_{3}\right]_{2}(70)^{\mathrm{c}}$ & 14 \\
\hline$p-\mathrm{C}_{6} \mathrm{H}_{4}\left[\mathrm{OP}(\mathrm{O})(\mathrm{OEt})_{2}\right]_{2}$ & $h \mathrm{v}, \mathrm{NH}_{3}, 1.5 \mathrm{~h}$ & $p-\mathrm{C}_{6} \mathrm{H}_{4}\left[\mathrm{SnPh}_{3}\right]_{2}(100)^{\mathrm{c}}$ & 14 \\
\hline
\end{tabular}

${ }^{\mathrm{a}}$ Only reduction in DMSO. ${ }^{\mathrm{b}}$ Naphthyl. ${ }^{\mathrm{c}}$ After the irradiation, Na metal was added. ${ }^{\mathrm{d}} \mathrm{Pyridyl} .{ }^{\mathrm{e}}$ Quinolyl.

\section{Other Tin-derived Nucleophiles}

When $p$-anisyltrimethyltin 2 reacts with sodium metal in liquid ammonia, the Sn-Me bond is cleaved to render nucleophile 16, after neutralization of the generated amide ions with t-butyl alcohol (eq. 12) [19]. This result is consistent with the bond dissociation energy difference between the tin-phenyl bond (347 kJ mol $\left.{ }^{-1}\right)$ [20] and the tin-methyl bond $\left(259-272 \mathrm{~kJ} \mathrm{~mol}^{-1}\right)[20,21]$. Nucleophile 16 was then allowed to react with $p$ chlorotoluene $\mathbf{1 7}$ under irradiation to afford substitution product $\mathbf{1 8}$ in almost quantitative yields (eq. 13). 
b) $t-\mathrm{BuOH}$

2<smiles>COc1ccc([Si](C)(C)c2ccc(C)cc2)cc1</smiles>

Product 18 was also obtained in a one-pot fashion starting from $\mathrm{Me}_{3} \mathrm{Sn}^{-}$and $p$-chloroanisole under photostimulation. Intermediate product 2 was not isolated, but treated in situ with Na metal to afford nucleophile 16, which by a subsequent photostimulated reaction in the presence of $\mathbf{1 7}$ rendered product $\mathbf{1 8}$ in $89 \%$ overall yield.

The photostimulated reaction of $p$-dichlorobenzene 5 with $\mathrm{Me}_{3} \mathrm{Sn}^{-}$ions in liquid ammonia affords the disubstitution product (6) (eq. 6). When this product is treated in situ first with $\mathrm{Na}$ metal and then with t-BuOH, dianion 19 is obtained, which upon addition of $\mathrm{PhCl}$ and ulterior irradiation (90 min) affords product 20 in a one-pot process (70\%) [16] (eq. 14).
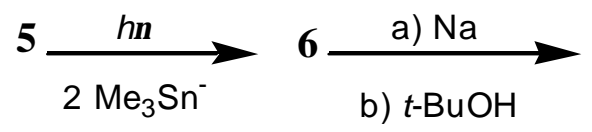

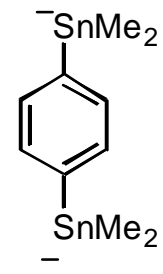

19

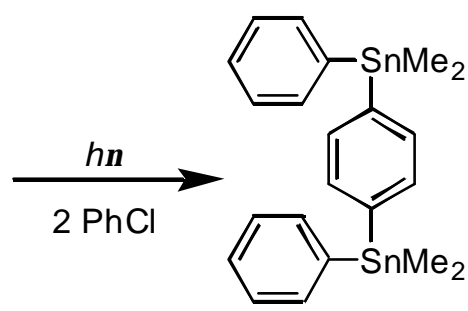

20

When $\mathbf{1 8}$ is treated with $\mathrm{Na}$ metal in liquid ammonia under the same reaction conditions as those employed above, nucleophile 21 is formed. Addition of $\mathrm{PhCl}$ followed by irradiation generates product $\mathbf{2 2}$ in $31 \%$ yield (eq. 15). The overall yield is significantly reduced in this case owing to the presence of products arising from some tin-aryl bond fragmentation. 


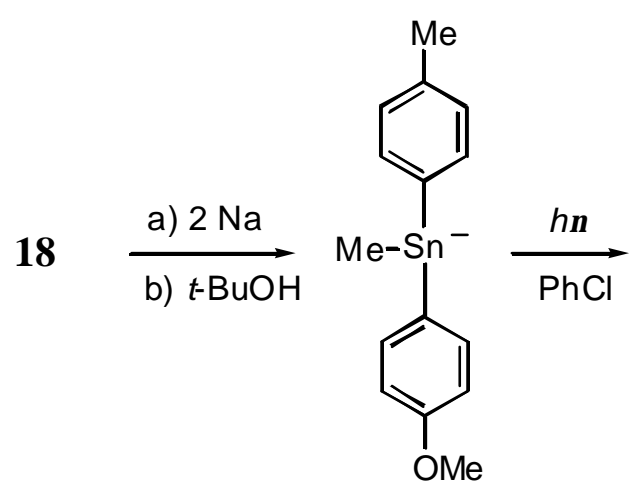

21<smiles>COc1ccc([Sn](C)(c2ccccc2)c2ccc(C)cc2)cc1</smiles>

22

When 22 is further treated with $\mathrm{Na}$ metal in liquid ammonia following the same procedures as utilized to form 16 or 21, nucleophile 23 is obtained. Upon photostimulation of 23 in the presence of 4-chlorobiphenyl, product 24, a chiral aromatic organostannyl compound, is obtained in $25 \%$ yield (eq. 16).

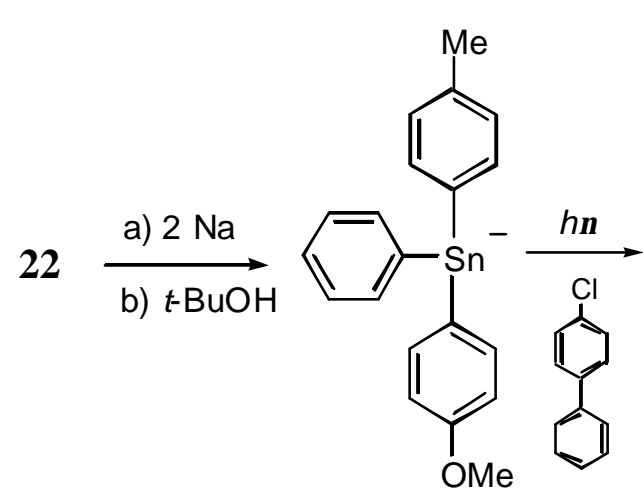

23

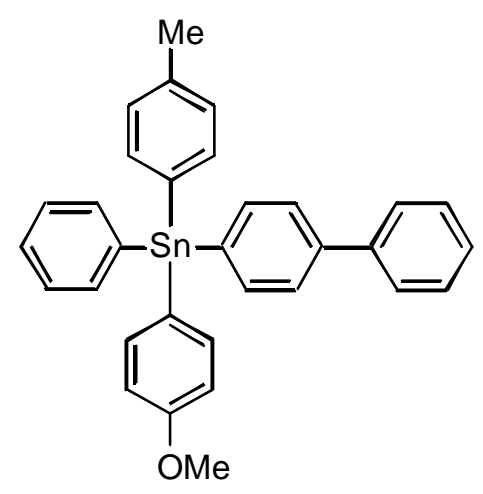

24

As mentioned previously, both alkyl-Sn and aryl-Sn bonds can fragment in the presence of Na metal in liquid ammonia, decreasing the selectivity of the fragmentation path. Selectivity towards alkyl-Sn bond fragmentation at the expense of aryl-Sn bond scission can be improved by exchanging the methyl group for another alkyl group with lower Sn-C bond dissociation energy. In fact, the cleavage of either n-butyltriphenyl tin (BDE $\left.(\mathrm{Sn}-\mathrm{Bu})=209 \mathrm{~kJ} \mathrm{~mol}^{-1}\right)[20]$ or benzyltriphenyltin $\left(\mathrm{BDE}(\right.$ Sn-benzyl $\left.)=163 \mathrm{~kJ} \mathrm{~mol}^{-1}\right)$ [22] leads exclusively to Sn-alkyl bond fragmentation.

\section{Synthetic Applications}

Aryltrialkyl stannanes are valuable intermediates in organic synthesis, and the fact that they can be easily synthesized through the $\mathrm{S}_{\mathrm{RN}} 1$ mechanism, opens up important synthetic routes to different reaction schemes. Halodemetallation of aryltrialkyl stannanes has been one such example [23]. The reaction of $\mathrm{Me}_{3} \mathrm{Sn}^{-}$ions with aryl chlorides with ulterior addition of iodine in $\mathrm{CHCl}_{3}$ has been used to obtain aryl iodides from aryl chlorides in very good yields [17].

For over a decade, the palladium-catalyzed cross-coupling of organotin compounds with carbon electrophiles, known as the Stille reaction [24], has been a very important tool in organic synthesis [25]. The reaction of $p$-cyanophenyltrimethylstannane 25 [26] with $\mathrm{PhI}$ and $\mathrm{Pd}\left(\mathrm{PPh}_{3}\right)_{2} \mathrm{Cl}_{2}$ as catalyst in $\mathrm{DMF}\left(80^{\circ} \mathrm{C}, 3\right.$ 
h), affords the coupling product 4-biphenycarbonitrile 26 in $81 \%$ yield (eq. 17) [27].<smiles>CSc1ccc(-c2ccc(-c3ccccc3)cc2)cc1</smiles>

The synthesis of the stannane and the Stille reaction were carried out in a one-pot procedure consisting of irradiating a liquid ammonia solution of $p$-chlorobenzonitrile and $\mathrm{NaSnMe}_{3}$, followed by quenching of the reaction by MeI [28]. The ammonia was allowed to evaporate, and the residue was taken up in DMF when $\mathrm{PhI}$, and $\mathrm{Pd}\left(\mathrm{PPh}_{3}\right)_{2} \mathrm{Cl}_{2}$ were added. Product 26 was obtained in $63 \%$ yield.

As shown before, high yields of disubstitution products can be obtained by the $\mathrm{S}_{\mathrm{RN}} 1$ mechanism from dichloro arenes and heteroarenes. For instance, when distannane $27 \mathbf{a}$ is heated at $80^{\circ} \mathrm{C}$ in the presence of $\mathrm{PhBr}$ and $\mathrm{Pd}\left(\mathrm{PPh}_{3}\right)_{2} \mathrm{Cl}_{2}$ in DMF, $m$-terphenyl 28a is obtained in $97 \%$ isolated yield (eq. 18). Under the same reaction conditions, the distannane $\mathbf{2 7} \mathbf{b}$ affords $p$-terphenyl $\mathbf{2 8 b}$ in $90 \%$ isolated yield.

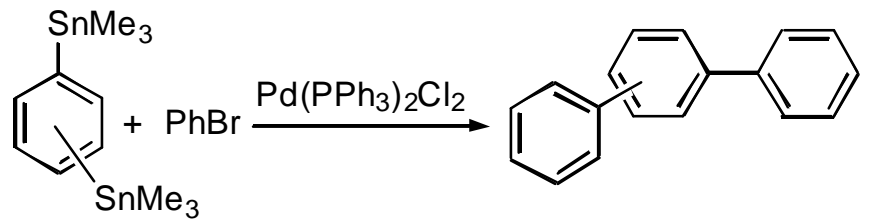

27a: $m$ -

27b: $p$ - 28a: $m-$

28b: $p-$

The one-pot photoreaction in liquid ammonia of $m$-dichlorobenzene and $\mathrm{NaSnMe}_{3}$ followed by quenching with MeI, evaporation of the ammonia, and redissolving in DMF in the presence of $\mathrm{PhBr}$ and $\mathrm{Pd}\left(\mathrm{PPh}_{3}\right)_{2} \mathrm{Cl}_{2}$ as described above, leads to product 28a in $76 \%$ yield. Following the same procedure but using $p$ dichlorobenzene, product $\mathbf{2 8 b}$ is obtained in $\mathbf{7 1 \%}$ yield. Reaction of 2,6-di(trimethylstannyl)pyridine with $\mathrm{PhI}$ and $\mathrm{Pd}\left(\mathrm{PPh}_{3}\right)_{2} \mathrm{Cl}_{2}$ affords diphenylated pyridine (72\%), along with 2-phenylpyridine (25\%). In the one-pot fashion, substrate 2,6-dichloropyridine rendered the diphenylated product in $60 \%$ overall yield.

A triphenylation reaction was conducted utilizing the tristannane 9. Upon reaction of 9 with $\mathrm{PhI}$ in the presence of catalytic $\mathrm{Pd}\left(\mathrm{PPh}_{3}\right)_{2} \mathrm{Cl}_{2}$, triphenylated product 29 was obtained in $89 \%$ yield (eq. 19). In the onepot procedure, 1,3,5-trichlorobenzene affords 29 in $61 \%$ isolated yield. 


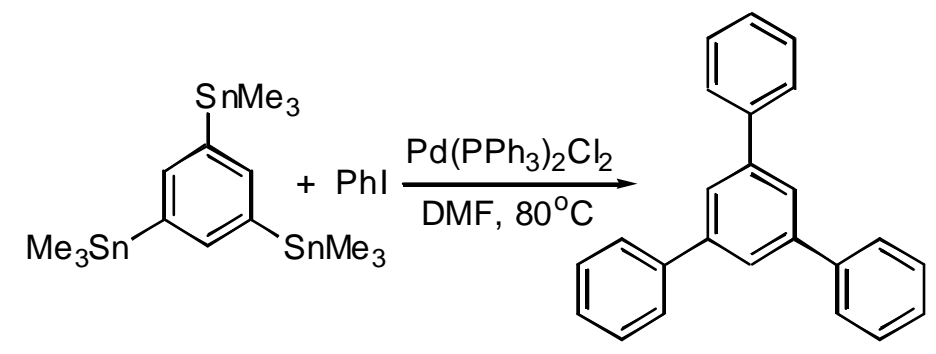

The fact that chloroarenes 30 react with $\mathrm{Me}_{3} \mathrm{Sn}^{-}$ions under photostimulation to form aryltrimethyl stannanes 31, and that in the Pd-catalyzed Stille reaction with stannanes the reactivity of iodoarenes is much greater than that of chloroarenes, a substrate bearing both leaving groups, $\mathrm{Cl}$ and $\mathrm{I}$, will react by the $\mathrm{C}$-I bond (product 32, eq. 20) and not by the $\mathrm{C}-\mathrm{Cl}$ bond, in a Stille-type reaction. This will allow the remainder leaving group, $\mathrm{Cl}$, to react later in another $S_{\mathrm{RN}} 1$-type reaction to form an organostannyl intermediate (product 33) which can ultimately furnish product $\mathbf{3 4}$ (eq. 21 ) by a palladium catalyzed cross-coupling.

$$
\begin{aligned}
& \mathrm{Ar}-\mathrm{Cl} \underset{\mathrm{S}_{\mathrm{RN}} 1}{\stackrel{\mathrm{Me}_{3} \mathrm{Sn}^{-}}{\longrightarrow}} \mathrm{Ar}_{-\mathrm{SnMe}_{3}} \underset{\mathrm{Pd}(0)}{\stackrel{\mathrm{I}-\mathrm{Ar}^{1}-\mathrm{Cl}}{\longrightarrow}} \mathrm{Ar}-\mathrm{Ar}^{1}-\mathrm{Cl} \\
& 30 \\
& 31 \\
& 32
\end{aligned}
$$

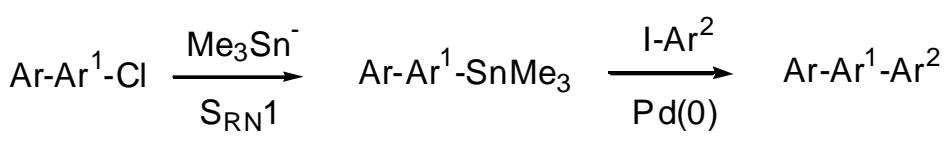

The above sequence, $S_{\mathrm{RN}} 1$ reaction-Pd catalyzed reaction- $S_{\mathrm{RN}} 1$ reaction-Pd catalyzed reaction was investigated in our laboratory in order to foster a methodology to build large molecules. The photo-stimulated reaction of $p$-chlorobenzonitrile 35 with $\mathrm{Me}_{3} \mathrm{Sn}^{-}$ion affords the stannane 25, which by a $\mathrm{Pd}(0)$-catalyzed reaction with $p$-chloroiodobenzene furnishes product 36 in $94 \%$ yield (eq. 22). [15]<smiles>N#Cc1ccc(Cl)cc1</smiles>

35<smiles>CSc1ccc(C#N)cc1</smiles>

25<smiles>N#Cc1ccc(-c2ccc(Cl)cc2)cc1</smiles>

36

By a photostimulated reaction of $\mathrm{Me}_{3} \mathrm{Sn}^{-}$ion in the presence of $\mathbf{3 6}$, stannane 37 is obtained in $94 \%$ yield. A second $\mathrm{Pd}(0)$-catalyzed reaction with 1-iodonaphthalene renders product $\mathbf{3 8}$ in $93 \%$ yield (eq. 23 ). 


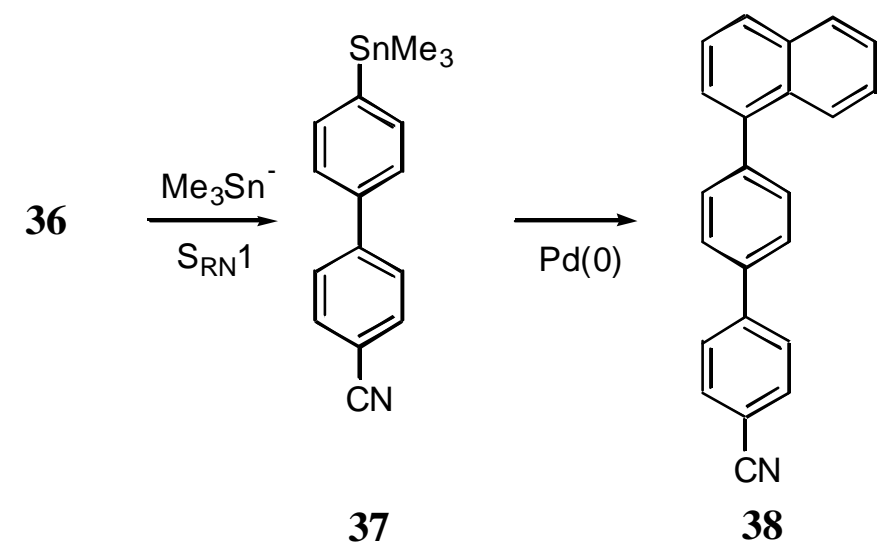

All these results indicate that the $\mathrm{S}_{\mathrm{RN}} 1$ mechanism is an excellent method to obtain stannanes by the photostimulated reactions of mono-, di- and trichloro arenes with $\mathrm{Me}_{3} \mathrm{Sn}^{-}$in liquid ammonia. The stannanes thus obtained can be arylated by further reaction with bromo or iodoarenes through palladium-catalyzed reactions. If the $\mathrm{Pd}(0)$-catalyzed reaction is performed with a chloroiodoarene substrate, the product obtained can be further arylated by a consecutive $\mathrm{S}_{\mathrm{RN}} 1$-Stille reaction.

\section{Conclusions and Summary Remarks}

The $\mathrm{S}_{\mathrm{RN}} 1$ reactions of trimethylstannyl and triphenylstannyl anions with haloarenes are quite versatile. The reaction products are of prominent synthetic relevance and can be utilized as intermediates in important reactions, such as the Stille reaction. Thus, the $S_{\mathrm{RN}} 1$ mechanism affords triorganyl stannyl aromatic compounds which otherwise would be synthesized by routes which employ harsher reaction conditions. The sequence $\mathrm{S}_{\mathrm{RN}} 1$-Pd-catalysis is a powerful synthetic tool, and the scope of the reaction is unlimited owing to the nature of the sequence, i.e. $\mathrm{ArX} \rightarrow \mathrm{ArSnR}_{3} \rightarrow \mathrm{ArAr}$, which can be iteratively repeated when appropriately substituted substrates are chosen.

Acknowledgements: We thank Professor A.B. Chopa for preprints of her results. This work was supported in part by the Consejo de Investigaciones, Provincia de Córdoba (CONICOR), the Consejo Nacional de Investigaciones Científicas y Técnicas (CONICET), SECYT, Universidad Nacional de Córdoba and FONCYT, Argentina. E.F.C gratefully acknowledges receipt of a fellowship from CONICET.

\section{References and Notes}

1. Wursthorn, K. R.; Kuivila, H. G; Smith, G. F. J. Am. Chem. Soc. 1978, 100, 2789

2. (a) Wursthorn, K. R.; Kuivila, H. G, J. Organometal. Chem. 1976, 105, C6. (b) Wursthorn. K. R., Kuivila, H. G.; G. F. Smith, J. Organometal. Chem. 1977, 140, 29.

3. Quintard, J. P. ; Hauvette-Frey S. J. Organomet. Chem. 1976, 112, C11. J. Organometal. Chem. 1978, 159, 147.

4. Carey, F. A.; Sundberg, R. J. Advanced Organic Chemistry, Part B; 3rd ed.; 1990: p 575 (and references cited therein).

5. For reviews, see: (a) Rossi, R. A.; de Rossi, R. H. Aromatic Substitution by the $S_{R N} 1$ Mechanism; ACS Monograph 178: Washington, DC, 1983. (b) Norris, R. K. Comprehensive Organic Synthesis; 
Trost, B. M., Ed. 1991, 4, 451; (c) Rossi, R. A., Pierini A. B., Peñéñory, A. B. in Recent Advances in the $S_{R N} 1$ Reaction of Organic Halides, The Chemistry of Functional Group; Patai S.; Rappoport, Z., Ed.; Wiley, Chichester: 1995; Supl. D2, Ch 24, pp. 1395-1485; (d) Rossi, R. A.; Pierini, A. B; Santiago, A. N. in Aromatic Substitution by the $S_{R N} l$ Reaction, Organic Reactions Vol. 54; Paquette, L. A.; Bittman, R., Eds.; 1999; pp. 1-271.

6. Azizian, H.; Heaborn, C.; Pidcock, A. J. Organometal. Chem. 1981, $215,49$.

7. Farina, V.; Krishnan, T. J. Am. Chem. Soc. 1991, 113, 9585.

8. Kelly, T. R.; Bridger, G. J.; Zhao, C. J. Am. Chem. Soc. 1990, 112, 8024.

9. (a) Gronowitz, S.; Peters, D. Heterocycles 1990, 30, 645; (b) Otsubo, T.; Kono, Y.; Hozo, N.; Miyamoto, H.; Aso, Y.; Ogura, F.; Tanaka, T.; Sawada, M. Bull. Chem. Soc. Jpn. 1993, 66, 2033; (c) Lamba, J. J. S.; Tour, J. M. J. Am. Chem. Soc. 1994, 116, 11723.

10. Yang, Y.; Wong, H. N. C. Tetrahedron 1994, 50, 9583.

11. Yamamoto, Y.; Azuma, Y.; Mitoh, H. Synthesis 1986, 564.

12. Yammal, C. C.; Podesta J. C.; Rossi, R. A. J. Org. Chem. 1992, 57, 5720.

13. Rossi, R.A.; Bunnett, J.F. J. Org. Chem. 1972, 37, 3570.

14. Chopa, A.B.; Lockhart, M.T.; Silvestri, G. J. Organometal. Chem. 2000, 19, 2249.

15. Córsico, E. F., Rossi, R.A. (submitted).

16. Córsico, E.F.; Rossi, R.A. Synlett 2000, 2, 227.

17. Yamamoto, Y; Yanagi, A. Chem. Pharm. Bull. 1982, 30, 1731.

18. Lochart, M.T; Chopa, A.B.; Rossi, R.A. J. Organometal. Chem. 1999, 582, 229.

19. Yammal, C. C. ; Podestá, J. C.; Rossi, R. A. J. Organometal. Chem. 1996, 509, 1.

20. Harrison, P.G., in Chemistry of Tin; Blackie: London, 1989; p. 13.

21. Jackson, R. A. J. Organometal. Chem. 1979, 166, 17.

22. Newmann, W. P. in The Organic Chemistry of Tin; Wiley-Interscience: London, 1970; p. 9.

23. Poller, R. C. in The Chemistry of Organotin Compounds; Academic Press: New York, 1970; pp. 3742.

24. (a) Milstein, D.; Stille, J. K. J. Am. Chem. Soc. 1978, 100, 3636; (b) Stille, J. K. Angew. Chem. Int. Ed. Engl. 1986, 25, 508.

25. For reviews see (a) Mitchell, T. N. in Metal Catalysed Cross-Coupling Reactions; Diedrich, F.; Stang, P.J., Eds.; Wiley VCH Verlag GmbH, Weinheim, 1998, pp. 167-202; (b) Farina, V.; Krishnamurthy, V.; Scott, W. J. in The Stille Reaction, Organic Reactions; Paquette, L. A., Ed.; 1997, Vol. 50, pp. 1652.

26. Prepared by the photostimulated reaction of $p$-chlorobenzonitrile and $\mathrm{Me}_{3} \mathrm{Sn}^{-}$ion in liquid ammonia in $85 \%$ isolated yield.

27. Córsico, E.F.; Rossi, R.A. Synlett 2000, 2, 230.

28. The excess of $\mathrm{NaSnMe}_{3}$ would react with methyl iodide to form $\mathrm{SnMe}_{4}$. It is more difficult to transfer a methyl group than a phenyl ring, see ref. 25. Toluene was not found in these reactions.

Samples Availability: Not applicable.

(C) 2000 by MDPI (http://www.mdpi.org). 